\title{
Micronutrient Supply from Pine Bark and Micronutrient Fertilizers
}

\author{
Alex X. Niemiera \\ Department of Horticulture, Virginia Polytechnic Institute and State \\ University, Blacksburg, VA 24061-0327
}

Additional index words. irrigation, container-grown, DTPA, soilless media, Pinus taeda

The average water-extractable micronutrient content of pine bark, with the exception of $\mathrm{Fe}$, is similar to Hoagland's micronutrient solution (Ogden et al., 1987). Yet, amending bark with micronutrients is a common nursery practice. Both positive plant growth responses (Penningsfield, 1972; Whitcomb, $1978,1984)$ and no growth responses (Conover et al., 1975; Leda, 1986) have resulted from the addition of micronutrients to container media. In one case, response to micronutrient addition was found to depend on addition of lime (Wright and Hinesley, 1991).

The method used for extracting micronutrients is important in assessing micronutrient availability. Berghage et al. (1987) and Handreck (1989) found the extractant diethylenetriaminepentaacetic acid (DTPA) to be a relatively reliable indicator of media micronutrient status. The quality of DTPAextracted micronutrients was highly correlated with growth (Handreck, 1989).

Container-grown nursery crops are irrigated with as much as $4500 \mathrm{~mm}$ of water per growing season, but the effect of this leaching on micronutrient supply has not been documented using DTPA as the extractant. Broschat and Donselman (1985), evaluating several micronutrient fertilizers, showed relatively constant micronutrient supplies over time in irrigated media; however, ammonium acetate, which has been shown to be a relatively poor indicator of media micronutrient status (Handreck, 1989), was used as the extractant.

Handreck (1989) determined the DTPA iron content of Pinus radiata D. Don bark, but no reports have documented the DTPA extractable $\mathrm{Cu}, \mathrm{Fe}, \mathrm{Mn}$, and $\mathrm{Zn}$ of pine $(P$. taeda L.) bark, Additionally, there have been no reports documenting DTPA extractable micronutrients from bark amended with micronutrient fertilizers. I, therefore, determined the DTPA-extractable micronutrient supply of pine bark amended with two micronutrient fertilizers (Micromax and Ironite) as influenced by irrigation rate.

Pine bark, amended with $3 \mathrm{~kg}$ dolomitic

Received for publication 16 July 1991. Accepted for publication 9 Oct. 1991, This work was sup ported by the Ironite Products Co. I greatly acknowledge the technical assistance of Joyce Shelton. The cost of publishing this paper was defrayed in part by the payment of page charges. Under postal regulations, this paper therefore must be hereby marked advertisement solely to indicate this fact. lime $/ \mathrm{m}^{3}$, was amended with $1 \mathrm{~kg}$ Micromax/ $\mathrm{m}^{3}$ (recommended rate; Grace-Sierra, Milpitas, Calif.) or 1 or $2 \mathrm{~kg}$ Ironite $/ \mathrm{m}^{3}$ (Ironite Products Co., Scottsdale, Ariz.) (Table 1). Micronutrient analysis of bark was (in $\left.\mathrm{mg} \cdot \mathrm{g}^{-1}\right): \mathrm{Cu}, 17$; Fe, 684; $\mathrm{Mn}, 63$; and $\mathrm{Zn}$, 34. Bark (50 g), including an untreated control, was put into $3.8 \times 15.2-\mathrm{cm}$ PVC tubes with one end of tubes covered in cheesecloth to allow for drainage. Tubes were drip-irrigated (distilled water, $1.3 \mathrm{ml} \cdot \mathrm{min}^{-1}$ ) with $0.24,0.48,0.72$, or 0.96 liters, which, on a volume basis, is equivalent to $30,60,90$, and 120 applications of $6.3 \mathrm{~mm}$ of water, respectively. Five tubes per irrigation $\times$ micronutrient treatment were stored at $22 \mathrm{C}$ and arranged in a randomized complete-block design. Following each irrigation, a modified saturated medium extraction (Berghage et al., 1987) was performed by adding 40 $\mathrm{ml}$ of 0.001 M DTPA to wet bark. After 45 min, the bark solution was vacuum-removed and tested for $\mathrm{Cu}, \mathrm{Fe}, \mathrm{Mn}$, and $\mathrm{Zn}$ using an atomic absorption spectrophotometer.

Irrigation rate had no effect on micronutrients extracted (data not shown); thus, concentrations were pooled over irrigations. Broschat and Donselman (1985) and Handreck (1989) showed a similar result for several micronutrient fertilizers in soilless media.

Copper, $\mathrm{Fe}, \mathrm{Mn}$, and $\mathrm{Zn}$ concentrations in bark extracts of Ironite and $\mathrm{Fe}$ and $\mathrm{Zn}$ concentrations of Micromax were essentially the same as those of the unamended bark (Table 2). There were significant differences for $\mathrm{Fe}$ and $\mathrm{Zn}$, but the milligram per liter difference most likely would not be physiologically significant in terms of plant growth. In contrast, the $\mathrm{Cu}$ concentration in the extract with Micromax was $\approx 50$ times greater than that supplied by the control or the Ironite-amended bark. The Mn concentration in the extract with Micromax was $\approx 50 \%$ higher than that from unamended or Ironite-amended bark. The higher concentrations of $\mathrm{Cu}$ and $\mathrm{Mn}$ in the extract with Micromax partly reflected the difference in $\mathrm{Cu}$ and $\mathrm{Mn}$ content of Micromax and Ironite (Table 1).

The similar $\mathrm{Fe}$ and $\mathrm{Zn}$ concentrations of control and amended bark may explain why there was no growth response to micronutrient additions (Conover et al., 1975; Leda, 1986). Apparently, bark supplies sufficient $\mathrm{Fe}, \mathrm{Zn}, \mathrm{Cu}$, and Mn to satisfy a plant's requirement for such elements. Cases in which plants respond to micronutrient additions may be explained, in part, by decreased availability or uptake caused by interactions with
Table 1. Micronutrient content of Ironite and Micromax ${ }^{z}$.

\begin{tabular}{lcccc}
\hline \hline & \multicolumn{4}{c}{ Content (\%) } \\
\cline { 2 - 5 } Source & $\mathrm{Cu}$ & $\mathrm{Fe}$ & $\mathrm{Mn}$ & $\mathrm{Zn}$ \\
\hline Ironite & 0.05 & 12.0 & 0.05 & 1.0 \\
Micromax & 1.1 & 12.0 & 2.5 & 1.0 \\
\hline
\end{tabular}

${ }^{2}$ Data supplied by manufacturer.

Table 2. Concentrations of micronutrients extracted from pine bark by means of diethylenetriaminepentaacetic acid.

\begin{tabular}{|c|c|c|c|c|c|}
\hline & Applicatior & & & & \\
\hline Amend- & rate & Extra & ct concr & $\mathrm{n}(\mathrm{mg} \cdot \mathrm{lit}$ & $\left.\operatorname{ter}^{-1}\right)$ \\
\hline ment & $\left(\mathrm{kg} \cdot \mathrm{m}^{-3}\right)$ & $\mathrm{Cu}$ & $\mathrm{Fe}$ & $\mathrm{Mn}$ & $\mathrm{Zn}$ \\
\hline None & -- & $0.10 \mathrm{~b}$ & $22.7 \mathrm{~d}$ & $9.7 b$ & $3.9 \mathrm{~d}$ \\
\hline Ironite & 1 & $0.12 \mathrm{~b}$ & $23.0 \mathrm{c}$ & $9.4 \mathrm{bc}$ & $4.3 \mathrm{c}$ \\
\hline & 2 & $0.14 \mathrm{~b}$ & $23.6 \mathrm{~b}$ & $9.0 \mathrm{c}$ & $4.5 \mathrm{~b}$ \\
\hline $\begin{array}{l}\text { Micro- } \\
\max \end{array}$ & & & & & \\
\hline $\max$ & 1 & $.0 \mathrm{a}$ & 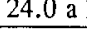 & $4.4 \mathrm{a}$ & $.8 \mathrm{a}$ \\
\hline
\end{tabular}

${ }^{2}$ Mean scparation within columns by Tukey's (HSD) test, $P=0.05$.

other fertilizers (Broschat and Donselman, 1985; Handreck, 1989) or pH (Korcak, 1987; Wright and Hinesley, 1991). Extract Fe concentrations of unamended bark were generally higher than those listed by Handreck (1989) for mostly Australian species. Research is needed to determine minimum micronutrient concentrations for other species.

\section{Literature Cited}

Berghage, R.D., D.M. Krauskopf, D.D. Warncke, and I. Widders. 1987. Micronutrient testing of plant growth media: Extractant identification and evaluation. Commun. Soil Sci. Plant Anal. 18:1089-1110.

Broschat, T.K. and H.M. Donselman. 1985. Extractable $\mathrm{Mg}, \mathrm{Fe}, \mathrm{Mn}, \mathrm{Zn}$, and $\mathrm{Cu}$ from a peatbased medium amended with various fertilizers. J. Amer. Soc. Hort. Sci. 110:196-200.

Conover, C.A., D.W. Simpson, and J.N. Joiner. 1975. Influence of micronutrient sources and levels on response and tissue content of Aphelandra, Brassia, and Philodendron. Proc. Fla. State Hort. Soc. 88:599-609.

Handreck, K.A. 1989. Assessment of iron availability in soilless potting media. Commun. Soil Sci. Plant Anal. 20:1297-1320.

Korcak, R.F. 1987. Iron deficiency chlorosis. Hort. Rev. 9:133-186.

Leda, C.E. 1986. Iron and manganese requirements of containerized plants growing in pine bark. MS Thesis, Virginia Polytechnic Inst. and State Univ., Blacksburg.

Ogden, R.J., F.A. Porkorny, H.A. Mills, and M.G. Dunavent. 1987. Elemental status of pine barkbased potting media. Hort. Rev. 9:103-131.

Penningsfield, F. 1972. Macro and micronutrient requirements of pot plants in peat. Acta Hort. 26:81-102.

Whitcomb, C.E. 1978. Micronutrient fertilizers on container-mown Ilex crenata 'Hetzi'. Amer. Nurseryman 148:10.

Whitcomb, C.E. 1984. Plant production in containers. 1st ed. Lacebark Publications, Stillwater, Okla.

Wright, R.D. and L.E. Hinesley. 1991. Growth of eastern red cedar amended with dolomitic limestone and micronutrients. HortScience 26:143-145. 